\title{
Brian Street and African American Feminist Practices: Two Histories, Two Texts
}

\section{Faye Spencer Maor - North Carolina A\&T State University KEYWORDS}

feminism; uplift; racial pride; racial responsibility; literacy; literacy practice; literacy workers

"One must also accede that the intersecting issues of race, culture, history and literacy produce a juncture of complexity that cannot be easily unsnarled by a single, definitive treatment."

-Joyce L. Harris, Literacy in African American Communities

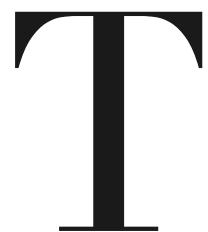

he literacy history of African Americans is long and complex, and here I offer a treatment of this complex history in light of the work of Brian Street. This study examines the lives, practices, and words of two important African American literacy workers and suggests that the work they did in the nineteenth century is an example of Street's ideological theory of literacy. Francis (Fanny) Jackson Coppin (b. 1837) and Hallie Quinn Brown (b. 1849) intentionally created written texts from which succeeding generations of literacy workers should learn. In this article, I try to fulfill what John Hope Franklin said was "the solemn obligation to rewrite the African American story from the perspective of the experiences and struggles of their own generation" (qtd. in Rudder 259). By focusing on these women and their work, I hope "it may be clear that critical examinations of how and why African Americans institutionalized their literacy traditions, passing them along to succeeding generations, contributing to the whole of American traditions, are potentially far more relevant and thoughtprovoking than descriptive accounts of literacy attainment" (Belt-Beyan 10).

The "who" and "why" of literacy is an ever-present question for me. It motivates and fascinates me. I believe the experiences of African American women and their literacy history can teach all of us a great deal about what various students bring to the classroom and that these histories can enrich our understanding and practice of literacy today. Brian Street's Literacy in Theory and Practice presents two models of literacy theories that he argues should make us all reconsider what we mean when we use literacy as a measure of opportunity, success, and civilization. Street writes that what "reading and writing are for a given society depends upon the context; that they are already embedded in an ideology and cannot be isolated or treated as 'neutral' or merely 'technical' .... I shall demonstrate that what practices are taught and how they are imparted depends upon the nature of the social formation" (Street, Literacy in Theory 1). That demonstration is what I try to 
do here as well. Two primary questions guide my work:

1. What were the literacy practices enacted by those who were born into slavery and marginalized by race and racist practices that allowed for the movement of teachers and their students to "create" and "form" a new community independent of and different from their previous social condition?

2. What is the ideology embedded in the social formation of literacy for African Americans post-slavery?

Candace Epps-Robertson writes that African Americans have believed "access to literacy and language has represented power" (2). Therefore, I read the texts of Coppin and Brown for ways of understanding the context of the "social formation" Street suggests, and the ways in which these women helped their students “access" power. I argue that these African American women's literacy practices in the nineteenth century are feminist/womanist and distinct. I also do a type of "recovery" work. Epps-Robertson explains the usefulness of recovery work in this way:

A look at recovery work in rhetoric and composition and literacy studies since the late 1990s (Enoch, Refiguring; Prendergast, Literacy; Gold, Rhetoric; Logan, Liberating; Moss, Community Text; Schneider, You Can't; Wan, Producing) demonstrates the interdisciplinary effort to understand histories of rhetoric and literacy for groups that were long ignored by mainstream scholarship. (2)

Therefore, this examination can help us to interrogate master narratives about literacy, race, and citizenship. I seek to add to and complicate the "master narrative" of literacy in general and African American literacy specifically.

While Coppin and Brown have been studied and written about, the focus is often on their feminist rhetoric and activist practices or they are simply noted for their speeches and as notable figures. For example, Jacqueline Jones Royster's book Traces of a Stream: Literacy and Social Change Among African American Women discusses Coppin as one of several outstanding African American women in the nineteenth century to lead the way in African American education and rhetoric. More recently, Hollis Robbins and Henry Louis Gates in The Portable Nineteenth-Century African American Women Writers collection provide not only Coppin's reprinted speeches but also writings about her life and work by one of her peers, S. Elizabeth Frazier. Finally, Susan Kates studies Brown's elocution texts in an article entitled “The Embodied Rhetoric of Hallie Q. Brown."

Less has been written about their texts as they relate specifically to their teaching practices. A close reading of Coppin's Reminiscences of School Days and Hints on Teaching and Brown's Bits and Odds: A Choice Selection of Recitations for School, Lyceum and Parlor Entertainments reveal the belief in and practice of a Black feminist/womanist ideological literacy. In fact, these women, and their texts, help us do what Street suggests: "To name something is to position it somewhere in the nexus of power relations that are sustained by the rhetorical force of the naming term" (Hager and Holiday, qtd. in "Literacy Inequalities"). In creating physical texts, Coppin and Brown "name" their practices and ideology, thereby positioning themselves, both then and now, in the power relations of rhetoric. These texts are intentional. These women meant their practices to continue. These texts helped create, form, and codify literacy ideologies and practices for African American students. 
To see what these texts offer literacy and composition studies, I provide a brief overview of African American literacy. Then I focus on the lives and texts of Coppin and Brown. Finally, I consider Coppin's and Brown's texts as Black feminist work connected to and carried on in important ideologies of well-known contemporary scholars in literacy, education, and African American studies, which in my view demonstrates a continuation of the feminist literacy ideologies found in Coppin's and Brown's texts. Brian Street's work helps us unpack these women's activities, texts, and teaching as encompassing a type of anthropological social literacy practice, while the examination here also aids us in understanding Street's work and how his ideas and theory might look in practice. Ultimately, my reading of these texts suggests a Black feminist ideological literacy model in action, which pushes against narratives of literacy deficiencies and instead embraces literacy "traditions," thereby seeing literacy in these groups as "adding to" rather than "creating or erasing.”

\section{African American Literacy Practices: Contributing to Communities}

The experiences of the Black community regarding citizenship and education often differ from the experiences of the White majority. Since the arrival of enslaved people in the Americas, access to literacy and language has represented power; nevertheless, acquisition of literacy has not remedied all problems of injustice. Beyond struggle and oppression, both Black adults and children have worked valiantly to provide their communities with access to educational opportunities when all else seemed to fail (Epps-Robertson 2). Coppin's and Brown's lives are evidence of this idea. An examination of Brown and Coppin reveals that literacy and schooling have not always been thought of as ways to power, proof of value, or paths to solving injustice, as Epps-Robertson suggests. While Coppin and Brown agree that literacy is important to all of those things, we also see that for many, literacy helps individuals contribute to the community. Maisha Fisher writes in Black Literate Lives: Historical and Contemporary Perspectives that "part of becoming 'literate' was to assume the responsibility to contribute to one's immediate and at-large community" (18).

African Americans have indeed made progress and contributed to our communities. Today we can say literacy rates of African Americans have increased; enrollments of African American students in all types of educational institutions surpass whatever could be imagined by many literacy workers of the late nineteenth century (Roser and Ortiz-Ospina). However, increases in enrollment and access do not always mean increased or improved literacy or acquisition of power. Yes, we have more scholars of color researching and writing in the field than ever before, and we have done much work to understand, dissect, and appreciate African Americans ways of using English, from Ebonics, which identified cultural and grammatical structures of African American language use, to code meshing, code switching, and vernacular resistance to community literacy to African American Vernacular English (AAVE). All this work has sought to understand and explain how language is used, within and against African American communities and individuals. We have come a long way.

However, there persists a need to be better, to understand, and to explore concepts of literacy 
in marginalized groups: from where do they come? What should we call these concepts, and, most of all, how can we practice them and utilize what we learn to teach those who need to develop dexterity in language use? Time and community have changed since the time of Brown and Coppin, and the African American community today is not the community of the women discussed here, a community of tight-knit neighborhoods-everyone on the block. Indeed, technological and social changes have affected the formation and appearance of that community. The African American community has changed. In many places children no longer stay in the same town as their parents and everyone who lives in the neighborhood is not known. Despite these changes and scattering, there remains a sense of African American community, and this sense of community continues to dictate that the acquisition of literate skills, reading, and writing was, and is, vital for members of the community to acquire. There is a need for understanding that individual acquisition and mastery of literacy has and/or should have a direct and far-reaching impact on the collective community, no matter how scattered or physically disconnected. We still associate literacy with power, but what that "power" is varies. Coppin said that when one rises to speak, especially in the halls of academia, the whole race rises (F. Coppin 15), and this sense of collective responsibility persists.

Few of the African American literacy workers of the nineteenth and early twentieth century left texts concerning their work. We have even fewer texts by African American women of that period on "how to teach." Instead, we must glean many of these women's legacies through studies of the number, diversity, and prominence of their students, who went on to become leaders in a plethora of professions and spaces. Their legacies are also found in discussions of institutions they founded, some of which are still in operation. Women like Coppin and Brown had knowledge and practices that allowed them to "develop language and literacy practices to resist White supremacist and economically motivated stereotypes conveying subhuman or immoral images" (Richardson 7475). Further, Richardson adds, "I see African American literacies as including vernacular resistance arts and cultural productions that are created to carve out free spaces in oppressive locations such as the classroom, the streets, the workplace, or the airwaves to name a few" (76).

Specifically, Brown carves a free space for herself through vernacular resistance in her text Bits and Odds. Coppin enacts her literacy practices by advising teachers to create classrooms as free spaces within the oppressiveness of male-dominated institutions through methodologies preserved in the Reminiscences of School Life and Hints on Teaching. Teachers' efforts to educate "their own" were often discouraged by attitudes that said it was useless to educate Black children in the classics or "academic subjects." They also had to fight against patriarchal attitudes and actions that tried to subvert, cover up, and appropriate their work. Coppin, for example, was criticized for having a classical curriculum at the Institute for Colored Youth, and after getting married she was expected to stop teaching. She did neither.

Coppin and Brown produced texts to discuss what they felt should happen to Black children in the classroom. These texts are pedagogical. Coppin's and Brown's commitments and efforts are also documented and should be studied and celebrated. We should discover why Coppin's name endures through institutions like Coppin State University in Baltimore, Maryland, which began 
as a teacher's college and was named for her because of her accomplishments in teacher training. Brown's name and legacy lives on through the Hallie Quinn Brown Library on the campus of Central State University in Ohio. What greater honor to bestow a literacy worker than to name a library after her? I see these women and their texts as a way of understanding African American literacy practices as "multiple and varied." This supports Street's point in "Literacy Inequalities in Theory and in Practice: The Power to Name and Define," that "ethnographic perspectives and an understanding of literacy practices as multiple and culturally varied, can help avoid simplistic and often ethnocentric claims regarding the consequences of literacy based on one-dimensional and culturally narrow categories and definitions" (580).

\section{Frances Jackson Coppin: Literacy of Responsibility}

Frances (Fanny) Jackson Coppin was born into slavery in 1837 in Washington, DC. Coppin benefited from the generosity of freed family members to gain her own freedom, most particularly her Aunt Sarah. She, in fact, remembered little of her time as an enslaved child. Coppin attended the Rhode Island State Normal School, where, she writes, "Here my eyes were first opened to the subject of teaching. I said to myself, is it possible that teaching can be made so interesting as this?" (F. Coppin 11-12). Subsequently, she went for further study at Oberlin College in Oberlin, Ohio, which was the only college open to women and African American students at the time. She was the second African American woman to successfully complete the gentleman's course, in which women were advised not to enroll at Oberlin. ${ }^{1}$

After her graduation from Oberlin, Coppin became principal of the female department of the Philadelphia Institute for Colored Youth (ICY). Four years later, in 1869, she became principal of the entire school (Cromwell 216). Coppin's legacy of care for students, in and out of the classroom, included the development of the Colored Woman's Exchange, which offered opportunities for the public to view the various artistic and practical accomplishments of the city's African Americans, and the founding of the Home for Girls and Young Women-a boarding house for young women in domestic service (F. Coppin 216). In 1881 she married Levi J. Coppin, who served as editor of the AME Christian Recorder and later became a bishop of the African Methodist Episcopal Church, of which Frances J. Coppin was a lifelong member. As M. A. Majors wrote in Noted Negro Women: Their Triumphs and Activities, published in 1893, Fanny Coppin "has probably attained more fame as a teacher than any of the noble Afro-American women of the age" (171). Bert Loewenberg and Ruth Bogin note a description of Coppin by a Philadelphia writer who said, "By common consent Mrs. Fanny Jackson Coppin ranks first in mental equipment, in natural gifts and achievement among colored teachers .... for more than thirty years she ... was the most thoroughly controlling influence in moulding the lives of the colored people of that great city [Philadelphia]" (as qtd. in Loweburg and Bogin, 302).

Coppin's only book, Reminiscences of School Life and Hints on Teaching, was published after her death in 1913 and is divided into two parts. Part I was completed prior to her death and contains a short autobiography and instruction on how to teach various subjects. Part II, while roughly 
drafted by Coppin, was completed for publication by her former student and colleague William Bolivar and focuses on notable students who attended the Institute. Bolivar says, of Coppin's desires for the book, that

[t]he spirit of altruism, the self-abnegations of a lifetime, were obvious in her motive in the other part she had planned. She meant that those who had helped her, and that some of the exceptional scholars from the school in which she had taught for nearly forty years, should be a part of her last effort. All the details, and all the persons noted in the pages to follow, were her thought, suggestion, and arrangement. (F. Coppin 137)

I focus here on Part I of Reminiscences of School Life and Hints on Teaching, which demonstrates Coppin's distaste for rote learning, drills, and memorization. Coppin practiced what some would call process and self-motivated learning, where critical thinking and reasoning were the preferred skills to be learned and practiced by her students (40). She advocated a style of teaching and learning that followed the process and need(s) of the individual students: "Growth in learning and acquisition proceeds slowly and by steps, and we must follow nature's direction" (40). In this quote, the phrase "nature's direction" points toward the needs of the student and not a set curriculum, a pedagogy that characterized much of Coppin's teaching and later her work as a trainer of teachers.

Coppin advises teachers, "Never let the word 'dumb' be used in your class, or anything said disrespectful of parents or guardians who have helped the child" (40). She discourages heavy reliance upon textbooks, a practical notion for the time. I believe she signals here the need to create or "customize" the curriculum for whatever situation the teacher confronts. This need also exists in many contemporary classrooms. In the $21^{\text {st }}$ century, many teachers continue to teach with limited resources such as textbooks, or materials of poor quality and demeaning rhetoric. Coppin tells teachers, whatever the difficulty, it can be overcome.

When reviewing work done by elementary students, Coppin tells us, "the pupils will profit by the criticism of one another, the teacher making no correction that can possibly be made by the class; thus inviting and stimulating critical knowledge and judgment of all" (41). Today we might call this peer review or a "flipped classroom"; Coppin calls it "co-operative correction" and says it not only benefits the student but also helps lighten the load of the teacher (46). Coppin's gentleness, kindness, love and devotion to students are suggested in chapters 4, 6 and 7 of Reminiscences and Hints on Teaching. These chapters are titled "Diagnosis and Discipline," "Punishment," and "Moral Instruction and Good Manners," respectively. Although the chapters are brief, Coppin offers instruction to teachers that emphasizes engaging the "whole" student. She instructs teachers to use love and kindness and always to be self-reflexive about what is happening in the classroom and the teacher's role in that classroom. Chapter four, "Diagnosis and Discipline," for example, begins this way:

It is possible for the teacher to notice who those are in the class who do not care for learning what we have to give them; and the question to ask ourselves is, Why? Are the lessons too hard? or are they too long? Is the child well? Above all, does he seem to pass from one to another part of study with ease and comfort to himself, or is he troubled and uncertain? (51) 
It seems Coppin rarely gave up on a student but instead sought to discover the difficulty or obstacle preventing the student from achieving or making progress in the areas the teacher desired. One method of successful diagnosis and discipline Coppin used was the individual and private examination: "Examinations privately conducted without letting the person know what you are looking for may give the true source of trouble" (52). Further, she admonishes teachers to be patient, wise, and skillful: "the teacher should be as conscientious in the endeavor to improve himself as he is to improve the child" (53). Here Coppin tells us the problem is not necessarily in the student. It may, in fact, be us, and we should work on ourselves to become better in helping the student.

Through every lesson, Coppin tries to motivate students to learn the subject that is being taught. For example, when advising teachers how to teach reading in the primary grades, she says, To learn to read, write and spell one word the first day, will be found to be very interesting to the children. The word "man" is a good word to begin with, because day after day by the addition of one more letter each day we can form a sentence. Words are more interesting than letters, and sentences are more interesting than words. So that as soon as possible the teacher wants to make a sentence. (65, emphasis added)

She calls for explicit teaching when she writes,

But it is not supposed that we should omit to teach the alphabet in order, for we know that this is necessary. But by no means allow this to be done mentally. Have the book or chart with the letters larger and distinctly made, and have the children's eyes follow the work as the teacher points to each letter and call its name.... But there can hardly be a better way to train a child to think and reason than by the constant comparisons which he has had to make use of in learning the letters and all about them. (65-66)

Coppin tells teachers specifically what should be taught. More important to Coppin is meaning. Meaning is all important (67) even when teaching the alphabet; Coppin encourages teachers not only to teach the alphabet but also to engage students in understanding what letters are. I believe this advice tells us that even learning to read for her students was an opportunity to also teach them the concept of what language is, why it is, and what it is used for. Coppin believes students should become able to get the meanings, concepts, "sense" of the letter, word/lesson before considering errors. At the same time, she admonishes teachers not to condemn home languages. She advises:

Do not stop to correct mis-pronounced words, but wait until the lesson has been read thru once. In this way we shall get the sense of the lesson. It is objected that if we leave the corrections until the reading is finished, they will be forgotten; but stopping after each one reads, to say what you noticed was wrong, etc., keeps the pupils from getting a connected idea of the lesson, and hence, destroys the interest in it. (67-68)

Here she privileges understanding over correctness.

Coppin's study and teaching of writing immediately follows her discussion of reading, primarily because she argues that writing reinforces reading and that "[f]ive words correctly defined and written in sentences are of more value than twenty words simply spelled correctly" (68). It is also through learning to spell and understand the meaning of words that Coppin suggests 
the rules of grammar and punctuation will be learned and understood. Thinking, reasoning, and stimulating interest in literacy as well as the materials used to develop that literacy are simultaneously important in her pedagogy. More specifically, Coppin uses an exercise in which students compose a letter to their mothers. Using this exercise, she argues, teaches both reading and writing. Coppin writes, “The child's interest is awakened, and he [sic] will try his best to learn other words that he will write to his mother. If this begins in the first reader [reading textbook], before the third is finished the child will be quite a little scribe" (69). She continues, "It is well worthwhile to let the child see how he is getting ahead. The English language is certainly not an easy one to learn, and much patience is required to learn and use it correctly; but a thoughtful teacher can by pointing out differences help the pupil to remember the many points necessary in correct reading and spelling" (69).

Literacy teachers today are still having debates and discussions about what kinds of readings we should use for our students. What kinds of readings have meaning and can capture and motivate the culturally and ethnically diverse students we teach today? Coppin had advice to teachers about that too. She writes:

There is a world of happy thoughts all about us, and if we make wise selections in teaching, they are quite sure to be remembered. And the grain of truth which they contain is as encouraging in bringing forth, as is the grain of mustard seed. What we sow we reap, and there is no field more fertile than that of a child's mind. If we plant tomatoes, we get tomatoes; we certainly should not expect to find potatoes. And so, if we plant beautiful thoughts and beautiful words in the child's mind, we shall certainly get the same. But I do not forget the parable of the tares of the field, for whatever we do, there is always an active enemy who is doing his sowing at the same time, and for this reason we must humble ourselves and pray that the Lord of the Harvest may protect our child's mind from the sower of evil; for in spite of all you may do, you will find things in that child's mind which you never taught, and which you cannot account for. (73)

In this quote, Coppin does not prescribe specific readings or writings to give students; instead she focuses us on what the reading selections should do, planting "beautiful" thoughts and words in the readers' minds. How can these beautiful thoughts and words be grasped by readers if those readings are divorced from the cultural and ethnic backgrounds of the reader? If ethnography involves the examination of customs and traditions of a people, then in the above quote, Coppin's use of religious imagery, traditionally used in African American rhetoric, both then and now, enacts the "ethnographic perspective" of literacy that Street describes. More specifically, her use of religious imagery to talk about teaching reading elevates the acquiring of reading skills to being divine, eliminating notions of students having a deficit. Street says an ethnographic perspective helps us shed notions of literacy as "deficit" and it "shifts us out of this mind set and helps us firstly to 'imagine' things that do not exist in our own world" ("Literacy Inequalities" 584). For Coppin, reading not only helps the student see "happy thought and truths, but it also is a divine skill, a thing of beauty. "Truths" are not imagined things. In our classrooms today, what materials do we use to help our students "imagine," or gain "happy thoughts," beautiful words and ideas? What does 
not exist in their worlds but that could? More specifically, how does Shakespeare create beautiful thoughts and truths for the student from Hendersonville, North Carolina?

Coppin's idea of reading practice goes hand-in-hand with writing as she suggests, As the pupils advance in their lessons, it will be a very good thing to have many little essays written on the power of words to bless or destroy and on the responsibility of those who use them, for "By thy words thou shalt be justified, and by thy words thou shalt be condemned." ... those whom we teach must be inspired to think about the different effect of kind words and unkind words, therefore, to think before they use them. (76)

I believe we see Street's ideological theory of literacy rooted in responsibility and liberal education though Coppin's emphasis on developing within students the responsibility words reading them and writing them. She tells teachers that they have the responsibility to teach students the power of words/language, and because language is powerful it must be used responsibility.

\section{Hallie Quinn Brown: The Literacy of Pride}

At the same time Coppin was teaching, Hallie Quinn Brown, slightly younger than Coppin, was an elocutionist, political activist, club woman, and teacher. She was one of the busiest and most productive African American literacy workers of the late nineteenth and twentieth centuries. Brown was born to a mother and father who were both slaves and of mixed blood (Black, Indigenous, and White). Because of his mixed heritage and prominent white family, Brown's father, Thomas Arthur Brown, despite being born a slave, was able to gain his freedom by working as a valet for his cousin, who was a United States Representative. After he purchased his freedom, he found employment as a steward and express agent on a steamboat. Thomas Brown served on the steamboat Pennsylvania, the very steamboat upon which Samuel Clemens received the name "Mark Twain" (McFarlin 14). As a result of his work on the steamboat, Thomas Brown was able to purchase property and afford what some would call a good living for his family. Hallie Quinn Brown's family, and particularly her father, had a profound effect on her and her work, as evidenced in the book Tales my Father Told, published in 1925. In this book, Brown provides an intimate portrait of her home life and retells childhood stories from her father regarding his adventures as a riverboat pilot and of her family's experiences hiding runaway slaves.

After living in Canada during the Civil War, when Brown was about the age of 18 or 19, the family moved back to the United States, and Brown was told she would be sent to school in Ohio. That school was Wilberforce University, the school Brown would be associated with for most of her academic career. According to Annjennette Sophie McFarlin, the Brown children had "experienced racial prejudice and humiliation. It was due to these experiences and other sorrows that Brown's parents decided she should go to a school that had been built for Black people, Wilberforce University" (19). At Wilberforce, Brown was to live and work with one of the greatest Black leaders of the time, Bishop Daniel Payne. He would also be her first and most influential mentor. Brown's discussions of her years at Wilberforce, 1868 to 1873, are loving, appreciative, and energetic in tone. She projects an image of the institution as young, but full of life, activity, and ambition, and she 
caught that energy herself: "I applied myself diligently to my books. Our school was in formation, wholly unorganized .... For the first time, I felt the spur of competition and delighted in having better class recitations than some of my older fellow students" (McFarlin 22). After graduating Wilberforce in 1873, Brown took a teaching position in South Carolina and then Yazoo City, Mississippi. Later she taught at Wilberforce University and served as president of women at Allen University in South Carolina.

In Yazoo City, Brown had to live in a one-room house with a family of three, people she had never met before. She had to compete with the needs and demands of the poor families, sharecropping, and the demands of the growing and harvesting seasons. The school building was dilapidated (McFarlin 28), but despite these conditions, she says she looked at the run-down schoolhouse and realized, "I could do it" (29). She immersed herself in the community, her work, the cause. During her time in Yazoo City, Brown succeeded in getting the school house built, and she is also credited with building a new church, starting Sunday School classes, and teaching "the women and girls on the plantation how to knit and sew and make flour bread" (30). She was so successful and effective that during the first year there that she was able to lengthen the school year from five to eight months and was offered another year's contract. However, she left Mississippi and went back to South Carolina because her parents felt rural Mississippi was too dangerous at that time for her to return (31).

In South Carolina, Brown accepted and completed her first public speaking, what was then called elocution, engagements. She says she gave her first performance in the woods of South Carolina on a tree stump: "A hundred dark faces with searching eyes peered into mine. It seemed unreal, uncanny under the light of wavering torches" (McFarlin 34). This was the beginning of what became the primary focus of her life's works in teaching and public life, public speaking, elocution.

An elocutionist is a person who has perfected the artistic style or manner of speaking or reading in public, one who is able to capture the meaning and feeling of an author and communicate its meaning and feeling naturally. Brown, who lived to be almost 100 years old, did her literacy work through public speaking, teaching, and writing. She wrote and published over eight texts and her fame, in terms of literacy work, was gained through her performances of recitations, readings, teaching and writings. Brown used her elocution skills to raise money for Allen University and her alma mater, Wilberforce, in England. One British minister, after attending a recitation in Liverpool, wrote to a former student of hers, "I know no English Elocutionist, man or woman, who recites with the naturalness and charm, the vivacity and power of Miss Brown. I never knew until tonight what the human voice could do"' (qtd. in Gomez-Jefferson 51). She was impressive in every way.

Brown's text Bits and Odds: Selections of Recitations for School Lyceum and Parlor Entertainments suggests an ideology of racial responsibility similarly to Coppin's, but Brown complicates and/or builds upon Coppin's notions to an ideology of racial pride. In a 1997 article, Susan Kates suggests that Brown's approach to elocution and her deliberate attention to the history and folk art of African Americans, as seen in Bits and Odds, is evidence of an ideology of literacy and education as "racial uplift," social responsibility, and more importantly, pride. Kates says, "By 
making language and history such important components of her elocutionary curriculum, Brown foregrounds the relationship between the development of cultural pride and social and political action" (67).

Like Coppin, Brown saw literacy, for the African American, as an instrument of service, strength, and pride, not just in the individual, but also in the community-the race. It is only through service, Brown says, that an individual's true gifts can contribute to his or her success, and education literacy is the vehicle through which one may become fit-capable, deserving evento serve. Brown argued, "The Great and ultimate object of all education is to fit the individual for service. One may be endowed with superior gifts, yet by neglect, or lack of use, utterly fail in the race of life" (McFarlin 173). Further, Brown saw her teaching and learning processes as activities that had, always, to embody two values-knowledge and discipline. Racial pride and the celebration of African American history and culture were ideals Brown pursued, and these ideals permeated her teaching, her performances, and her politics. Language was the fuel that powered and moved Brown's philosophy of racial responsibility and service as well as the ideal of racial/ cultural pride and history.

Brown's life and writings give an interesting view of not only her ideologies of literacy, but also her ideologies of human behavior and purpose. Faustin Delany's introduction to Bits and Odds suggests that in elocution, it is vital for the student to feel the emotions and thoughts of the author. The call for the student to feel the thoughts and emotions of the writer, I believe, helps the student develop empathy and care for the author, to understand the emotions of the author, to see how another person might be experiencing life. In turn that empathy for the author demands from the elocutionist a sense of the responsibility to listener. "It is not essential for him [sic] [the student] to lose his individuality. The reader has more to do than to imitate. He must feel and then express those feelings .... It is the cultivation of our own natures that is aimed at and not the imitation of the nature of another" (Brown, Bits and Odds 6; emphasis added).

Connection and responsibility to the author and listener might be why Kates calls Brown's use of language in Bits and Odds an embodied rhetoric, a rhetoric that gave, and gives, life, form, and shape to the ideals, philosophies, cultures, and histories of African American literacy. Kates argues that Brown's selections are purposeful with the intent of meeting and serving the needs of African Americans (59). Brown's purposeful selection of readings encourages and demands a cultural literacy of the pupils and the audience. Kates writes,

She [Brown] raised questions about the relationship between schooling and social responsibility, using and transforming mainstream elocutionary theory in order to address these issues. The goal of Brown's pedagogy was an "embodied rhetoric," that is to say, a rhetoric located within, and generated for, the African-American community. (59) An example of what Kates describes is seen in the selection, "Brother Watkins," a humorous story of a minister breaking the ice with a new congregation, and it utilizes the vernacular and mannerisms of black preachers that may have been common in the nineteenth century. By including the selection "Brother Watkins," Brown makes disinterested knowledge explicit knowledge. For example, to read "Brother Watkins" correctly, emphasis must be placed at the end of certain 
words. For example, "My beloved brederin before I take my text, I must tell of parting with my old congregation-ah on the morning of last Sabbath-ah" (Brown, Bits and Odds 34). If Faustin Delaney suggests, or demands, the elocution pupil must feel the emotions and thoughts of the author, and that the reader must use his/her own knowledge and feelings to express those feelings, then "Brother Watkins" forces the reader to enter into a realm and world of African American language and culture, and the expression of the feelings, I argue, requires valuing and respect. To recite "Brother Watkins," the elocutionist has to become "literate" in the culture, history, and language of the people in the story. He or she must appreciate, and be responsible for, the vernacular as it is if he/she wants to understand it and recite and communicate the author's meaning.

In this collection, Brown calls for not only a literacy of language, but also a literacy of community, culture, and language practices. She values the literacy in these communities as it exists. Inclusion of pieces like "Brother Watkins" shows a valuation of community, culture, and experience. This demonstration of racial responsibility and respect-the demonstration that cultural stories and traditions have value and can and should be used in a person's educationwas unique in the day. We are still battling for the acceptance, appreciation, and use of AAVE in formal writing. Just as in the nineteenth century, we still fight the notion that those who do not use spoken and written Standard English are those who are uneducated, and those who are uneducated are those of whom we should be ashamed. This idea is not exclusive to African Americans.

Consequently, I believe Brown goes much further than merely enacting a pedagogy located in, and for, the African American community.

However, Brown not only uses selections that use Black or African American dialect; she also uses pieces that require the reader and reciter to speak with Irish, Yiddish, and German accents, and/or dialects. The accents and dialects are not from the so-called "educated" classes, but rather, she calls for the reader to enter, acquire, and "perform" various cultural literacies. Bits and Odds requires the reader to adopt feeling for, and performance of, English in various vernaculars, thereby creating a literacy phenomenon consisting of multiple models of literacies that can be valuable to the field (Street, Theory and Practice). For African American students, and others interested in Brown's text, these pieces force them to go beyond their culture and become sensitive to, and respectful of, the cultures and experiences of others. Brown's collection is radical, challenging, entertaining, and educational. Brown believed elocution was one of the primary ways a student could become literate, educated, and cultured. Delaney suggests,

The elocutionist has a broader field. He [sic] has not so much to do with giving forth the original thoughts and feelings of his own mind as he has in giving forth those thoughts and feelings he has created in his mind, suggested by the expressed words of another, and causing the listener on the other hand to start the kindred chords vibrating in union with his own. (Brown, Bits and Odds 5)

Elocution challenged and educated its practitioner and audience. Through serious study and development of the discipline, students would come to an appreciation and pride in the diversity of the world. Brown's collection forces both the reader and audience to interact with, understand and merge their experiences, finding a common ground upon which the reader and audience become 
one-transcending racial and cultural differences.

\section{Feminist Black Literacy and Brian Street}

Literacy workers like Brown "create" a pedagogy and ideology that encompasses the various worlds and positions in which they found themselves. Jacqueline Jones Royster asserts that African American women write out of what she called their "multivocal" abilities. More specifically, she writes:

They [African American women writers] convey an intent to satisfy (more comprehensively than just one mode can do) two imperatives: to enact their own complex expressive purposes and to meet a range of audience needs. One might say that these writers embrace the notion that what they feel compelled to say is not only worth saying more than once but also worth hearing in more than one way. (22)

Black feminist ideology argues that literacy for African Americans must be comprehensive, holistic, and encompass all the intersections through which a Black woman moves and exists. More specifically, Black feminism seeks to explore how race, sex, class, work, education, and religions impact one's life. Beverly Guy-Sheftall, in Words of Fire: An Anthology of African American Feminist Thought, delineates five premises of black feminism. Among those premises are that black women work and live in a type of "triple jeopardy" of oppression due to sexism, racism, and classism, and because of that triple jeopardy, the needs of Black women are not the same as those of white women. Black women have to simultaneously struggle for equality and liberation from racism (2). Consequently, "black women intellectuals have always engaged in important philosophical ideas of their time, utilizing, developing and critiquing these ideas as they saw fit in order to address concerns of race, gender, and more specifically their place in social systems in which their race, gender and sexuality designated them as absences from intellectual life" (Davidson, Gines, and Marcano 3).

In this brief examination of two Black women of the nineteenth century, we see Brown and Coppin enact Black feminist work. The double jeopardy of being women and African American informs their work in every way. In addition, Coppin's and Brown's texts challenged the places in the social systems they were supposed to occupy. The nineteenth century is known for its cult of true womanhood where women were expected to devote themselves primarily to the establishment and keeping of a home, children, and husband. Brown never married and was once stranded in Arkansas after a tour she was on collapsed. Instead of panicking, she performed her way back to the East coast. Coppin married a man younger than she and refused to stop working after the marriage. Her husband, Bishop Levi Coppin, reflects on this in his autobiography, An Unwritten History. He says after he married Coppin, he wanted her to stop teaching. Of that the Bishop says, “There are two ways to stop an automobile, viz., to slow down, or, to run the machine against a stone wall” (L. Coppin 358). Neither Coppin or Brown let marriage or social norms, practices, and expectations stop their work.

This against-the-grain determination by Coppin and Brown do exactly what Street calls for 
when he says, "An ethnographic perspective shifts us out of this mind set and helps us firstly to 'imagine' things that do not exists in our world and then understand them in their own terms rather than to see them, in our terms, just as a 'deficits"' (Street, "Literacy Inequalities" 584). These women lived and worked in a world that never thought of them, their people, their sex as fully human or equal. They, by the very color of their skins, were "deficits," but they did work in which they had to "imagine" themselves, their students, their futures as equal, literate, and empowered. Further they could not, as both women and pioneers, see literacy or education as a "single uniform thing called 'literacy"' (Street, "Inequalities" 580). Street's work enables current scholars to go beyond examining the work of Coppin and Brown as recovered histories and portraits of activism. His work enables us to see and, hopefully, enact in the $21^{\text {st }}$ century, their techniques and pedagogies as an anthropological and social approach to literacy.

Literacy must provide skills to meet immediate needs while also developing and challenging the intellect. Coppin and Brown did not see the need for compromising literacy formation in an ideology of either/or, and the creation of the texts of this study are evidence of their resistance to that "either/or" ideology. Coppin and Brown believed and worked with the notion that all African Americans should, and could, gain a literacy for the complete person, a literacy that would give them the skills to establish and maintain a solid economic base, as well as acquire the intellectual prowess to negotiate the dominant white world. They resisted other nineteenth century educators like Booker T. Washington, who argued that African American students wasted time studying Greek and Latin, and W. E. B. DuBois, who advocated for a "talented tenth" who should pursue a classical "higher" education and subsequently "lift" the rest of the race. Brown and Coppin are feminists/womanists, women who worked for all.

\section{Twentieth Century Echoes}

Frances Jackson Coppin's literacy practice is embedded in an ideology of literacy as a privilege and responsibility. Her rhetoric points to a belief that excelling in literate practices was one of the best ways to prove to the white society in which she lived the humanity of a people once thought of as nothing but property; and as a former slave who had an education, Coppin was obligated to and responsible for aiding all members of her race in reaching her level of achievement and beyond. Her work centered around "lifting" everyone she could, in whatever ways she could, not just the lifting of a talented few, as DuBois advocated. As a woman, Coppin struggled to enact her ideologies in a male-dominated world. Even though many teachers in Black post-slavery classrooms were women, the philosophies, ideologies, and pedagogies of the profession were largely male. Coppin's feminist approach did not place limitations on what a student could do, regardless of background or social and economic standing. For Coppin, a student's social and economic standing were all considered in literacy practices to find multiple ways to meet students' multiple needs. This pedagogy requires that the teacher, through self-reflection and formal and informal assessment of students, constantly measure her effectiveness. Are students reaching their goals? Are the methods and approaches to learning accomplishing the goals set by the teacher? The answers to 
these questions dictate change. This pedagogy requires change when change is needed.

I first saw the influence of Coppin's ideology and methods of teaching reflected in important scholars like Lisa Delpit. In her book, Other People's Children: Cultural Conflict in the Classroom, when clarifying her position on the skills/process debate concerning writing instruction, Delpit writes,

I am proposing a resolution for the skills/process debate. In short, the debate is fallacious; the dichotomy false .... [T] hose [teachers] who are most skillful at educating black and poor children do not allow themselves to be placed in "skills" or "process" boxes. They understand the need for both approaches, the need to help students establish their own voices, and to coach those voices to produce notes that will be heard clearly in the larger society. (46)

Here Delpit's point is exactly the aim in Coppin's and Brown's work. Delpit entered the scene at the height of the process vs. skills pedagogy debate and came to her conclusions after reflecting on why African American students seemed to want more from her when teaching in a university, more than what she offered in the classroom: her secret to success, the details of how she got to be a university professor. She felt African American students looked for her "secret to success," namely because they looked at her as an African American who had the "secret" to how to write and speak at the white school. It is this expectation of her, on the part of her students, that led her to research and write about perceptions of literacy and how it is taught for, and to, African Americans. Delpit's use of the term "coach," in reference to the teacher, in relation to students, is a reflection of Coppin's statement that "he [the student] must educate himself under the direction of the teacher" (F. Coppin 44). Delpit and Coppin enact literacy that desires to empower students in their own learning. The teacher serves to direct and assist as part of her pedagogy. Coppin, working with an ideology of racial responsibility, knew what African American students would face once they left school.

Before Delpit, Geneva Smitherman, the pioneer of what we now call African American Vernacular English (AAVE) as a tool to better educate black students, says, in Talkin' and Testifyin': The Language of Black America, "Black dialect is an Africanized form of English reflecting Black America's linguistic-cultural African heritage and the conditions of servitude, oppression and life in America" (2). Therefore, the way many African Americans speak reflects ways of knowing that have played vital roles in the survival of black people in America. Further, Smitherman says, the way African Americans speak must be valued, celebrated, and used to spread literacy in meaningful ways to students, especially black students. Smitherman agrees with Brown's and later Carter G. Woodson's thinking when, in The Mis-Education of the Negro, he says African Americans have been taught to speak and write "correctly," not for the purpose of instilling pride in themselves, or their culture, let alone critical thinking and analysis. The emphasis on "correctness" Smitherman contends, directs African American students toward the values of the dominant culture (Smitherman 203). Notions that provoke negative images and thinking about AAVE, she argues, derive within a type of "black pathology" - the notion that something is not "normal" with African Americans (202). "Normal" is being white and middle class. However, speaking and using "correct" 
English, Smitherman says, does not ensure success, and she therefore discourages the connotation of the word "uplift" as the idea of making one white. This is the fight of the technical outlook Street laments.

African Americans' educational achievement is the result of pedagogies centered in the individual teacher. It is in making these pedagogies literacy workers should add to their resources. Smitherman writes,

I contend that it is still individual teachers in their individual setting that are the single most important factor in the educational process. The individual teacher has a tremendous impact on, and responsibility for how, what and how much students learn.

Smitherman goes on to say, "What is needed to prevent further mis-education of black kids is a change in teacher attitude and behavior, a complete reordering of thought about the educational process and place of black students in that process" (217). This change partly consists of a change in negative attitudes toward and respect for students' "home language." Negative attitudes, she argues, "negatively impact the teacher's ability to effectively teach that student (Smitherman 219)." In 2020, these conversations continue.

Brown is of like mind, reclaiming and using AAVE, as well as other ethnic forms of English, in her instruction. In order to teach the recitations, in Bits and Odds, written in vernacular forms, instruction regarding that form's grammatical and rhetorical structures and patterns would have to be taught and understood, which is what Smitherman, and others, call for. Brown says, "It is not essential for him [the elocutionist] to lose his [her] individuality. He must feel and then express those feelings .... It is the cultivation of our own natures that is aimed at and not the imitation of another" (Bits and Odds 6). Brown tells us, in 1880, a person does not have to forfeit their culture to gain a high level of literacy and appreciation for other cultures. What must happen, however, is that the student must cultivate and nurture what they already have and bring to the text and make it grow and blossom. Further, like Coppin, Brown, and Delpit, Smitherman says the role of the teacher in literacy teaching is to "... serve as guide, question, raise points and examples" (Smitherman 224). She goes on to write, "What teachers would be doing, then, amounts to a social and political act, which, like charity, begins at home" (241). For women like Brown and Coppin, the classroom was never a place devoid of the influence and importance of identity. Racial identity was key to Brown's and Coppin's motivations and persistence. The classroom was a place where racial identity, racial responsibility and racial pride met, mingled, battled, and cooperated. After all, for both Coppin and Brown, literacy was key to their status and success in a post-slavery world.

\section{We Do What We Do}

"I do not see how a teacher can succeed well without ingenuity, because ways of finding means to an end must be discovered by the teacher."

(F. Coppin 42) 
Making a way outa no way is what they did. Coppin's enslavement and work as a maid to becoming a world-famous teacher, and Brown's education at a new, small, black college, first working as a teacher in a school house with dirt floors and gaps between wall boards, and then becoming a world famous elocutionist performing for the Queen of England, demonstrate these women's abilities to make ways outa no ways. For Coppin and Brown, the need for a distinct approach, attitude, and concept of education was dictated and necessitated by the social condition of slavery, prejudice, and racism. Literacy was a principle of the African American slavery and post-slavery culture that was internalized as vital to the success and continuation of an African American community and culture.

I have tried in this article to do some of what Abul Pitre suggests needs to be done in the text African American Women Educators: A Critical Examination of Their Pedagogies, Educational Ideas and Activism from the Nineteenth to the Mid-Twentieth Century. Pitre says, "While scholars have sought to understand how to prepare teachers to effectively teach African American students, few have used the historical experiences of African American women educators as a tool to gain insight about effective pedagogical strategies" (1). Although classrooms of the nineteenth century and twenty-first century are quite different, as are the societal and cultural contexts, relationships, and connections exist between teachers then and teachers now. We continue to encounter many of the issues, dilemmas, and debates Coppin and Brown faced, and the need for effective solutions remains. I believe the texts examined here and the recovery of them can aid us in finding more complex and holistic solutions. Coppin and Brown believed and worked with the notion that all African Americans should, and could, gain a literacy for the complete person, a literacy that would give them the skills to establish and maintain a solid economic base, as well as acquire the intellectual prowess to negotiate the dominant white world.

We still have to make a way outa no way, for students, for we must overcome and make headway in the battle against the much-lamented phenomenon of African American students' continued academic underachievement, alienation from schooling, low self-esteem and low expectations from teachers, and social violence and misinformation. We must look back for what persists. The societal and educational climate of the nineteenth century may have been more oppressive than it is today, but a disconnect from core community survival themes and literacy practices might be key to our survival. Here I have tried to provide another perspective/history of two important women who codified us their work in texts about their work. Street writes,

An alternative perspective shifts the focus from schools and from children and instead sees reading and writing as always taking place in some specific sociocultural context. One is never "learning to read"; one is ever only "learning to read some specific text or other in a specific context." It is the sociocultural context and the practices that take place within it that give reading (and writing) its meaning. ("Learning" 336)

The sociocultural context Street speaks of clearly impacts the ideologies, philosophies, and practices of Brown and Coppin. Their texts reflect practices born out of experiences in multiple worlds-lands of existence-the land of the slave and freedwoman, white, black, literate and illiterate. Like theirs, our pedagogies are also shaped by real-life experiences and desires, social 
contexts. A Black feminist lens on the work of Street helps some who know nothing about the "Black experience" of women to engage in Black feminist ideological literacy.

In "Society Reschooling," Street reviews Shirley Brice Health's Words at Work and Play: Three Decades in Family and Community Life, a follow up to her classic, Ways With Words, and a British edited collection entitled, The Great Literacy Debate: A Critical Response to the Literacy Strategy and the Framework for English. These texts, Street writes, suggest that we must consider teaching what we might call "home," or everyday, literacies, at the same time we try to "teach" what we call "formal" or school literacy. Instead of "home" and "formal literacies being seen as opposites, they might be seen as necessary to a literacy strategy that meets students/people's needs. For me this notion points directly to Guy-Sheftall's premise of Black feminism that delineates the multiple stresses/jeopardy it seeks to liberate us from. Therefore, a literacy strategy that encompasses both formal and informal literacies might be one to facilitate that liberation. I believe Coppin and Brown used their version of Street's ideas to negotiate and embody their own Black feminism and ideology. We have much to learn from both.

We must renew our view of the work of women like Coppin and Brown not just for their political and activist histories but also for their pedagogical lessons and practices. We must, like them, use our public spaces to initiate change in order to do what Royster notes in Traces of a Stream: Literacy and Social Change Among African American Women: "engage in complex discursive practices that mirror the complex social, historical, and cultural positions from which they speak. ... engage in a 'simultaneity of discourse,' speaking in the creation of a single text both in a plurality of voices and in a multiplicity of discourses" (Royster 20). The coupling and examination of Coppin and Brown through the work of Street demonstrates a goal of literacy studies: "to enhance our capacity to build a more richly endowed knowledge base, carry out a more inclusive research agenda, and generate greater, more inclusive interpretive power" (Royster and Kirsch 134).

Brian Street, Frances Coppin, and Hallie Brown believed in an ideological model approach to literacy instruction. What I have briefly examined here is a small part of the collective resource of their teaching with their hearts, bodies, and minds. We must preserve, study, name, and use what has been left for us, and by doing so, place them, and ourselves, in a legacy of literacy practices that recognizes and grapples with who we are as we relate to the cultural, racial and, social history through which we view literacy. Then, perhaps, we will serve all our students more profoundly. Street's notion of the "social formation" of literacy, in light of African American and African American feminist practices, helps create a richer "interrogation" of literacy narratives. Perhaps we might also be able to re-evaluate and present practices and approaches that might be more antiracist, or, at the least, more empowering for both students and teachers. 


\section{NOTES}

${ }^{1}$ Oberlin had two courses for men and women. The "Women's Course" focused on literature and music, while the "Gentlemen's Course" focused on ancient languages, mathematics and the sciences. 


\section{WORKS CITED}

Belt-Beyan, Phyllis M. The Emergence of African American Literacy Traditions: Family and Community Efforts in the Nineteenth Century. Praeger, 2004.

Brown, Hallie Q. "A Great Slight to the Race.” Editorial. The Freeman [Indianapolis, Indiana], 30 Apr. 1892. Accessed July 2019.

Brown, Hallie Quinn. Bits and Odds: Selections of Recitations for School, Lyceum and Parlor Entertainments. Chew P, 1880.

---. “First Lessons in Public Speaking (1920).” Appendix C, “Sample Manuscript of Text.” McFarlin pp. 156-172.

---. Homespun Heroines and Other Women of Distinction. Aldine Publishers, 1926. https://docsouth. unc.edu/neh/brownhal/brownhal.html. Accessed Nov. 2020.

---. "Not Gifts but Opportunity.” Appendix C, “Sample Manuscript of Text.” McFarlin pp. 173-181.

---. Tales My Father Told and Other Stories. Ohio, Eckerle Printing Company, 1925.

Coppin. Francis J. Reminiscences of School Life and Hints on Teaching. Philadelphia, AME Book Concern, 1913. https://docsouth.unc.edu/neh/jacksonc/jackson.html.

Coppin, Levi J. Unwritten History. Philadelphia: AME Book Concern, 1919.

Cromwell, John W. The Negro in American History: Men and Women Eminent in The Evolution of the American of African Descent. The American Negro Academy, 1914.

Davidson, Maria del Guadalupe, Kathryn T. Gines, and Donna-Dale L. Marcano, editors. Convergences: Black Feminism and Continental Philosophy. SUNY P, 2010.

Delpit, Lisa. Other People's Children: Cultural Conflict in the Classroom. The New P, 1995.

Epps-Robertson, Candace. Resisting Brown: Race, Literacy, and Citizenship in the Heart of Virginia. U of Pittsburgh P, 2018.

Fisher, Maisha T. Black Literate Lives: Historical and Contemporary Perspectives. Routledge, 2009.

Gomez-Jefferson, Annetta L. The Sage of Tawawa: Reverdy Cassius Ransom, 1861-1959. Kent State UP, 2002.

Guy-Sheftall, Beverly, editor. Words of Fire: An Anthology of African-American Feminist Thought. The New P, 1995.

Harris, Joyce L., Kamhi, Alan G., and Karen Pollock, editors. Literacy in African American Communities. New York. Routledge, 2000.

Hollis, Robbins, and Henry Louis Gates, Jr. The Portable Nineteenth-Century African American Women Writers. New York: Penguin Classics, 2017.

Kates, Susan. “The Embodied Rhetoric of Hallie Quinn Brown.” College English, vol. 59, no. 1, 1997, pp. 59-71.

Lowenburg, Burt James, and Ruth Bogin. Black Women in Nineteenth-Century American Life: Their Words, Their Thoughts, Their Feelings. Pennsylvania State UP, 1976.

Majors, M. A. Noted Negro Women: Their Triumphs and Activities. Chicago, Donohue and Henneberry Printers, 1893.

McFarlin, Annjennette Sophie. Hallie Quinn Brown-Black Woman Elocutionist. 1975. Washington 
State University, $\mathrm{PhD}$ dissertation. http://ncat.idm.oclc.org/login?url=https://www-proquestcom.ncat.idm.oclc.org/docview/302780628? accountid=12711. Accessed Aug. 2019.

Perkins, Linda Marie. Fanny Jackson Coppin and the Institute for Colored Youth: A Model of Nineteenth Century Black Female Educational and Community Leadership, 1837-1902. 1978. University of Illinois Urbana-Champaign, $\mathrm{PhD}$ dissertation. http://ncat.idm.oclc.org/login?url=https://wwwproquest-com.ncat.idm.oclc.org/docview/302900836? accountid=12711. Accessed Aug. 2019.

Pitre, Abul. "Introduction: Education, Leadership, and Transformative African American Women Educators." African American Women Educators: A Critical Examination of Their Pedagogies, Educational Ideas, and Activism from the Nineteenth to the Mid-Twentieth Century, edited by Karen A. Johnson, Abul Pitre, and Kenneth L. Johnson, Rowman \& Littlefield Education, 2014, pp. 1-3.

Richardson, Elaine. African American Literacies. Routledge, 2003.

Robbins, Hollis, and Henry Louis Gates. The Portable Nineteenth-Century African American Women Writers. New York; Penguin Books, 2017.

Roser, Max, and Esteban Ortiz-Ospina. "Literacy." Our World in Data, 2013, ourworldindata.org/ literacy. Accessed 2 Aug. 2019.

Royster, Jacqueline Jones. Traces of a Stream: Literacy and Social Change Among African American Women. U of Pittsburgh P, 2000.

Royster, Jacqueline Jones, and Gesa E. Kirsch. Feminist Rhetorical Practices: New Horizons for Rhetoric, Composition, and Literacy Studies. Southern Illinois UP, 2012.

Rudder, Justin A. "Grassroots Historians and African American Historiography in Alabama." Alabama Review, vol. 72 no. 4, 2019, p. 259-300.

Smitherman, Geneva. Talkin' and Testifyin': The Language of Black America. Houghton Mifflin Co., 1977.

Street, Brian V. "Learning to Read from a Social Practice View: Ethnography, Schooling and Adult Learning." Prospects, vol. 46, 2016, pp. 335-44.

---. "Literacy Inequalities in Theory and Practice: The Power to Name and Define." International Journal of Educational Development, vol. 31, no. 6, 2011, pp. 580-86.

---. Literacy in Theory and Practice. Cambridge UP, 1984.

---. "Society Reschooling." Reading Research Quarterly, vol. 47, no. 2, 2012, pp. 216-27.

Wada, K. "Daniel Alexander Payne (1811-1893)." https://www.blackpast.org/african-americanhistory/payne-daniel-alexander-1811-1893/. Accessed 30 Nov. 2020.

Woodson, Carter G. The Mis-Education of the Negro. The Associated Publishers, 1977. 